\title{
PENGEMBANGAN VARIAN RASA PRODUK KRIPIK PISANG INDUSTRI RUMAH TANGGA DI KECAMATAN PERCUT SEI TUAN
}

\author{
Yulita Triadiarti', Akmal Huda Nasution', Ade Chairunnisa Gultom² \\ ${ }^{1}$ Fakultas Ekonomi, Universitas Negeri Medan, Medan, Indonesia \\ ${ }^{2}$ Fakultas Teknik, Universitas Negeri Medan, Indonesia \\ *Penulis Korespondensi: yulitatriadiarti@gmail.com
}

\begin{abstract}
Abstrak
Kegiatan pengabdian kepada masyarakat adalah pemberdayaan masyarakat untuk mengembangkan kegiatan sosial ekonomi, khususnya para ibu-ibu rumah tangga untuk meningkatkan perannya dalam keluarga maupun masyarakat, merangsang kelompok untuk dapat mandiri dalam membangun ekonomi keluarga dengan melakukan usaha-usaha produktif, dan memberikan tambahan pengetahuan dan pengalaman berorganisasi maupun mengatur pengelolaan keuangan. Kelompok Usaha Kripik Pisang ini belum pernah mendapatkan pembinaan dari pemerintah. Masalah utama yang mereka hadapi adalah kurangnya modal, minat, serta keterampilan dalam berinovasi. Kurangnya alat seperti mesin press (oven) kripik pisang menjadi kendala untuk belajar. Masih terbatasnya pengetahuan mengenai peluang usaha dan kemampuan mengetahui trend pasar, serta kurangnya pengetahuan mengenai pengelolaan keuangan dan kelayakan usaha yang akan di jalankan. Masalah tersebut mengurangi minat dan motivasi masyarakat untuk belajar dan berusaha. Melalui kegiatan pengabdian masyarakat ini diharapkan anggota kelompok dapat mengembangkan potensinya sehingga dapat meningkatkan taraf hidup keluarga dengan memberikan pelatihan dan pendampingan kewirausahaan untuk memberdayakan anggota kelompok melalui usaha ekonomi produktif. Pendekatan yang di lakukan pertama kali adalah memberikan pemahaman dan pengertian bahwa membangkitkan industri rumah tangga dimaksudkan untuk menjadikan masyarakat yang mandiri dalam mengembangkan perekonomian. Berusaha menumbuhkan semangat berwirausaha dalam meningkatkan pendapatan rumah tangga melalui usaha ekonomi produktif. Karena pengentasan kemiskinan di Indonesia di lakukan dengan pemberdayaan masyarakat untuk memperbaiki dan meningkatkan kesejahteraan masyarakat. Pendekatan kedua, adalah dengan memberikan materi mengenai pengelolaan keuangan dan kelayakan usaha yang di jalankan. Tahap selanjutnya adalah dengan memberikan alat mesin press (oven) guna menunjang kelancaran usaha yang selalu menjadi kendala dalam menyelesaikan pesanan.
\end{abstract}

Kata Kunci: Pemberdayaan, Pendampingan dan pelatihan kewirausahaan, kelompok usaha industri rumah tangga.

\begin{abstract}
Community service is community empowerment to develop socio-economic activities, especially housewives to improve their role in family and society, stimulate groups to be self-reliant in building family economy by conducting productive efforts, and provide additional knowledge and experience organize and manage financial management. This business group of Banana Chips has never received coaching from the government. The main problem they face is the lack of capital, interest, and skills in innovating. Lack of tools such as a press machine (oven) banana chips became an obstacle to learning. Limited knowledge about business opportunities and ability to know market trends, and lack of knowledge about financial management and business feasibility to be run. The problem reduces people's interest and motivation to learn and work. Through community service activities it is expected that group members can develop their potential so as to improve the living standard of the family by providing training and entrepreneurship assistance to empower group members through productive economic endeavors. The first approach is to provide understanding and understanding that generating home industries is intended to make people self-sufficient in developing the economy. Seeks to foster entrepreneurship spirit in increasing household income through productive economic effort. Because poverty alleviation in Indonesia is done by empowering the community to improve and improve people's welfare. The second approach, is to provide material on financial management and business feasibility in the run. The next stage is to provide a tool press machine (oven) to support the smooth business that is always a constraint in completing the order.
\end{abstract}

Keywords: empowerment, mentoring and entrepreneurship training, business group of home industry. 


\section{PENDAHULUAN}

\subsection{Analisis Situasi}

Pisang ( Musa Paradisiaca L.) merupakan tanaman yang banyak tumbuh di Indonesia. Pisang juga merupakan salah satu buah yang kaya akan manfaat. Pisang memiliki kandungan kalori sekitar 90 kalori serta memiliki kandungan gula yang lengkap. Negara Indonesia termasuk penghasil pisang terbesar karena sekitar 50 persen produksi pisang di Asia berasal dari Indonesia. Di Sumatera Utara sendiri sentra penghasil pisang berada di daerah Padang sidempuan, Natal, Samosir, Tarutung, dan Deli Serdang.

Pemasaran pisang sangat baik, ini dikarenakan harga pisang yang relatif murah sehingga memiliki banyak peminat. Untuk mengkonsumsi pisang bisa dengan dimakan langsung atau diolah sebagai cemilan salah satunya dibuat menjadi keripik pisang (Banana Chips). Keripik pisang merupakan alternatif pilihan cemilan yang hemat dan praktis. Pisang yang cocok dibuat keripik yaitu pisang nangka dan pisang kepok.

Produksi pisang di Indonesia menduduki tempat kelima dengan besaran 3,6 juta ton atau $5 \%$ dari produksi dunia. Kabupaten Deli Serdang merupakan Kabupaten yang luas lahannya sebesar 3.186 Ha dan yang paling besar produksinya sebesar 72.715 Ton di Provinsi Sumatera Utara. Deli Serdang merupakan Kabupaten dengan produksi pisang tertinggi di Provinsi Sumatera Utara yaitu sebesar 367.431 kuintal pada tahun 2013. Menurut (Anonim, 2015) produksi pisang dari Kabupaten Deli Serdang pada tahun 2014 produksinya sebanyak 298.305 Ton. Menurut (Anonim, 2006) Kabupaten Deli Serdang menempati area seluas $2.497,72 \mathrm{Km} 2$ yang terdiri dari 22 Kecamatan dan 394 Desa/Kelurahan Definitif. Wilayah Kabupaten Deli Serdang disebelah Utara berbatasan dengan Kabupaten Langkat dan Selat Malaka, disebelah Selatan dengan Kabupaten Karo dan Simalungun, disebelah Barat berbatasan dengan Kabupaten Langkat dan Karo dan disebelah Timur berbatasan dengan Kabupaten Serdang Bedagai.

Potensi sektor pertanian khususnya holtikultura cukup besar bagi masyarakat di Kabupaten Deli Serdang, Sumatera Utara. Kabupaten Deli Serdang memiliki luas lahan $249.772 \mathrm{Ha}$ dimana terdapat lahan sawah seluas $43.802 \mathrm{Ha}$ dan lahan kering/darat yang digunakan untuk tanaman pangan dan holtikultura 59.537 Ha yang terdiri dari kebun 40.082 Ha, ladang $12.477 \mathrm{Ha}$ dan lahan pekarangan 7.012 Ha (Rangkuti dan Wirdan, 2008). Data produksi pisang di Kecamatan Batang kuis sebanyak 1.820 pohon, Kecamatan Beringin sebanyak 2.500 pohon dan Kecamatan Biru-biru sebanyak 150.000 pohon.

Kelompok usaha keripik pisang Melur dan Lestari yang berada di Kecamatan Percut Sei Tuan, yang beranggotakan lima orang. Usaha mitra ini diprakarsai oleh ibu Evi dan ibu Hesti. Usaha ini merupakan usaha rumahan (Home Industry) dengan memberdayakan ibu-ibu rumah tangga sekitar dan remaja wanita putus sekolah. Masyarakat atau ibu-ibu di sekitar usaha memiliki perekonomian yang lemah, yang ingin memiliki penghasilan tambahan tetapi belum jelas usaha apa yang akan dikerjakan.

Keripik pisang dengan rasa gurih hasil olahan mitra ibu Evi dan ibu Hesti laris dipasaran. Keripik pisang yang diproduksi hanya ada satu jenis dengan rasa gurih seperti keripik pisang pada umumnya. Ini merupakan suatu kendala bagi usah yang ditekuni ibu Evi dan ibu Hesti karena banyak permintaan konsumen yang menginginkan keripik pisang dengan variasi lain tetapi ibu Evi dan ibu Hesti belum bisa memenuhinya. Hal itu disebabkan karena belum ada keterampilan atau pengetahuan tentang mengkreasikan kripik pisang supaya berbeda dengan kripik pisang yang dijual pada umumnya.

Keripik pisang bisa diberi tambahan coklat dengan keju yang dinamakan dengan kripik pisang coklat dan kripik pisang keju. Selain menambah cita rasa yang lebih nikmat, coklat juga dapat memberikan efek menghilangkan stress serta memberikan rasa senang karena cokelat mengandung molekul psikoaktif yang tentunya membuat pengkonsumsi cokelat merasa nyaman. Beberapa kandungan cokelat seperti caffeine, theobromine, methyl-xanthine dan phenylethylalanine dipercaya dapat memperbaiki mood, mengurangi kelelahan. Sedangkan pada keripik pisang keju mengandung itamin $C$, vitamin B6, vitamin $\mathrm{B}-12$, vitamin $\mathrm{A}$, vitamin $\mathrm{D}$, vitamin $\mathrm{E}$ dan vitamin $\mathrm{K}$ yang berguna bagi kesehatan tulang dan kesehatan gigi.

Pisang adalah buah yang kaya akan manfaat karena pisang mengandung kandungan gula yang lengkap yaitu glukosa, surkosa dan fruktosa. Kandungan kalori pisang sekitar 90 kalori, kandungan kalori tersebut termasuk tinggi untuk kategori buah buahan.Tidak sedikit orang yang menyukai buah pisang mulai dari anak-anak, remaja dannorang dewasa bahkan para olahragawan banyak yang menyukai buah pisang sebagai pemulih stamina sehingga kebutuhan energy akan tergantikan setelah melakukan aktifitas olahraga. Namun buah pisang mudah busuk, hal ini membuat saya berfikiran untuk mengawetkanya dengan mengolahnya menjadi cemilan dari pisang yang dibuat keripik kemudian mengkreasikannya dengan tepung coklat dan Keju. Sehingga pisang tersebut mempunyai rasa yang bervariasi dengan dua rasa sekaligus yang biasanya keripik pisang pada umumnya hanya memiliki satu rasa saja. Pisang yang cocok dibuat keripik adalah pisang ambon, tanduk, nangka dan kepok.

Eksistensi usaha industri rumah tangga memang tidak dapat diragukan lagi karena terbukti mampu bertahan dan menjadi roda penggerak ekonomi keluarga. Disisi lain, usaha industri rumah tangga juga menghadapi banyak sekali permasalahan, yaitu terbatasnya modal kerja, Sumber Daya Manusia yang 
rendah, dan minimnya penguasaan ilmu pengetahuan serta teknologi dan kreatifitas yang kurang. Kendala lain yang dihadapi adalah keterkaitan dengan prospek usaha yang kurang jelas serta perencanaan, visi dan misi yang belum mantap. Hal ini terjadi karena umumnya industri rumah tangga bersifat menaikkan pendapatan yang merupakan usaha milik keluarga, menggunakan teknologi yang masih relatif sederhana.

Penduduk Deli Serdang pada tahun 2015 sebanyak 2.029.308 orang dengan kepadatan penduduk sebanyak 812 orang per kilometer persegi. Jumlah rakyat miskin dari tahun 2009-sekarang terus menerus mengalami penurunan. Dari 94.800 jiwa $(5,7 \%)$ menjadi $91.440(5,17 \%)$. Berdasarkan data dari BPS Sumatera Utara, angka itu merupakan daerah berpenduduk miskin terendah dari 33 kabupaten/kota yang ada di Sumatera Utara. Deli Serdang juga mengalami kenaikan pendapatan perkapita pertahun 28,24 juta. Kemudian, pertumbuhan ekonomi meningkat secara signifikan yakni mencapai 7,77\% dengan jumlah penduduk 1,7 juta jiwa. Dengan keadaan ekonomi yang bertumbuh ini tentu menaikkan pendapatan masyarakat, serta naiknya kebutuhan konsumsi penduduk.

Merebaknya industri rumahan, tentu ikut berperan serta dalam menaikkan pendapatan masyarakat. Peran pemerintah dalam mendukung usaha kecil menengah tentu saja mempunyai andil besar untuk menaikkan taraf hidup masyarakat. Untuk itu dalam usaha meningkatkan taraf hidup rakyat miskin, maka usaha industri rumah tangga ini wajib di dukung dan di dampingi untuk pengembangan usahanya.

\subsection{Permasalahan Yang Dihadapi Oleh Mitra}

Pemberdayaan usaha industri rumah tangga di tengah arus globalisasi dan tingginya persaingan membuat usaha rumahan ini harus mampu mengadapi persaingan, seperti mengembangkan varian rasa produk, memperbaiki berntuk dan rasa produk semakin baik lagi, pengembangan sumber daya manusia dan teknologi. Mungkin sudah banyak pesaing produk ini yang menggunakan rasa lain untuk keripik pisang ini. Namun dalam produk ini memiliki keunggulan dengan memanfaatkan buah asli bukan perasa buah serta buah yang digunakan mengandung vitamin antioksidan yang dapat menvegah kanker sehingga dapat menjadi cemilan yang sehat. Pemasaran produk ini dilakukan dengan menitipkan di sejumlah warung atau toko, pemasaran melalui mulut ke mulut dan melalui pameranpameran UKM yang kerap dilaksanakan di Sumatera Utara, khususnya di Kabupaten Deli Serdang.
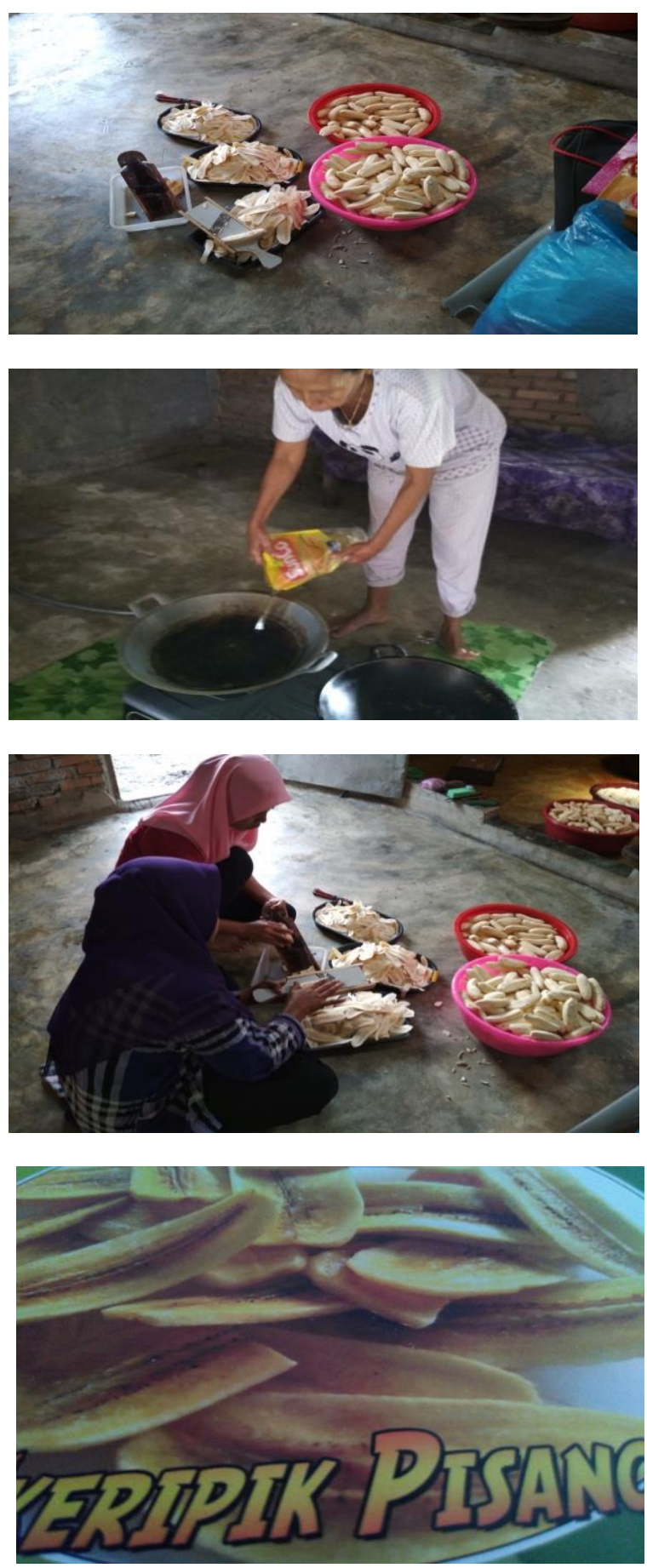

Gambar1. Kondisi Mitra

\section{SOLUSI DAN TARGET LUARAN}

\subsection{Solusi yang ditawarkan}

Solusi yang diusulkan dalam pelaksanaan kegiatan pengabdian masyarakat ini adalah dengan memberikan pendampingan motivasi berusaha dan kewirausahaan. Kegiatan ini dilaksanakan bertujuan untuk meningkatkan daya kreativitas masyarakat dibidang kuliner khususnya usaha kripik pisang.

Untuk mencapai tujuan kegiatan pengabdian tersebut, maka rancangan pelatihan/penyuluhan yang diharapkan dapat terlaksana adalah sebagai berikut: 
Tabel 2.1.

Solusi Aplikatif Terkait Permasalahan Mitra

\begin{tabular}{|c|c|}
\hline Permasalahan & Solusi \\
\hline $\begin{array}{l}\text { Aktivitas } \\
\text { pelatihan/penyuluhan } \\
\text { yang belum ada }\end{array}$ & $\begin{array}{l}\text { Memberikan } \\
\text { pemahaman mengenai } \\
\text { kewirausahaan dan } \\
\text { pendampingan motivasi } \\
\text { sebagai modal awal } \\
\text { dalam mengembangkan } \\
\text { usaha } \\
\text { Mengembangkan } \\
\text { daya kreativitas dibidang } \\
\text { kuliner dalam bentuk } \\
\text { Kelompok Usaha } \\
\text { Bersama }\end{array}$ \\
\hline $\begin{array}{lr} & \text { Kurangnya alat } \\
\text { untuk } & \text { menunjang } \\
\text { produksi dan latihan } \\
\text { bagi } & \text { anggota } \\
\text { kelompok } & \\
\end{array}$ & 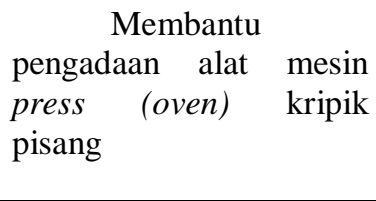 \\
\hline \begin{tabular}{l}
\multicolumn{1}{c}{ Kurangnya } \\
pengetahuan mengenai \\
menganalisis \\
permintaan pasar
\end{tabular} & \begin{tabular}{lr}
\multicolumn{3}{c}{ Memberikan } \\
pelatihan & serta \\
pengarahan & secara \\
teoritis dan teknis & ts \\
mengenai analisis & pasar \\
(analisis SWOT) &
\end{tabular} \\
\hline
\end{tabular}

\subsection{Luaran Yang Dihasilkan}

Dari pemaparan sebelumnya telah di jabarkan permasalahan yang dihadapi, untuk itu tabel di bawah ini menggambarkan luaran yang dihasilkan dalam kegiatan pengabdian kepada masyarakat dari tim pengusul.

Tabel 2.2.

Luaran dari Setiap Solusi

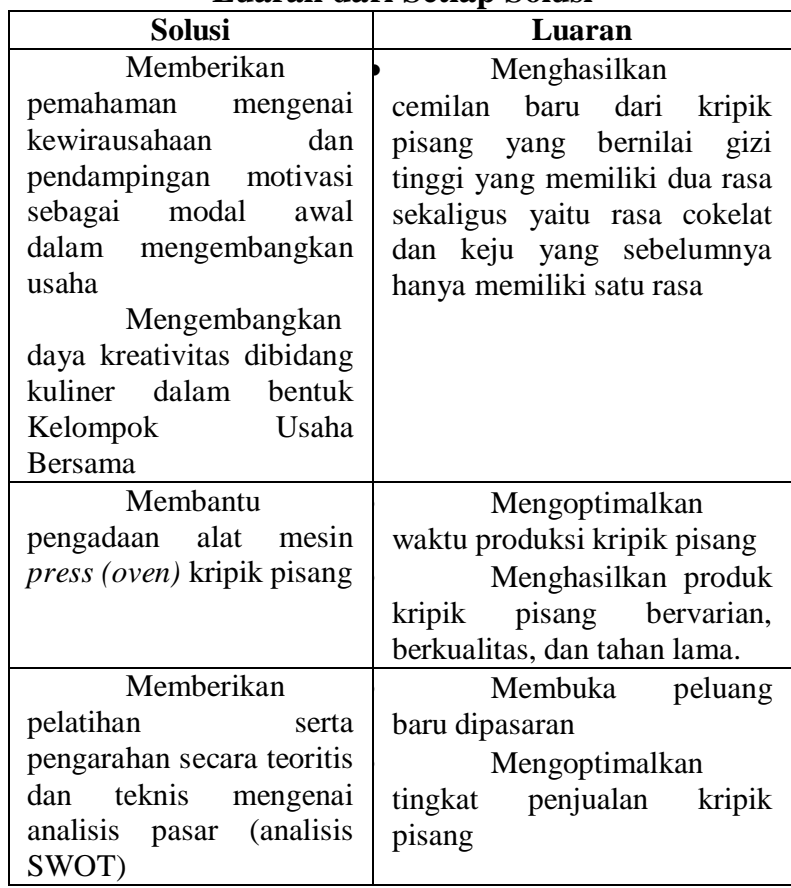

\section{METODE PELAKSANAAN}

\subsection{Pelaksanaan Kegiatan}

Secara grafis, tahapan pelaksanaan kegiatan Pengabdian Masyarakat ini di ilustrasikan didalam gambar 3.1 dibawah ini:

Gambar 3.1.

Tahapan Pelaksanaan Kegiatan Pengabdian Masyarakat

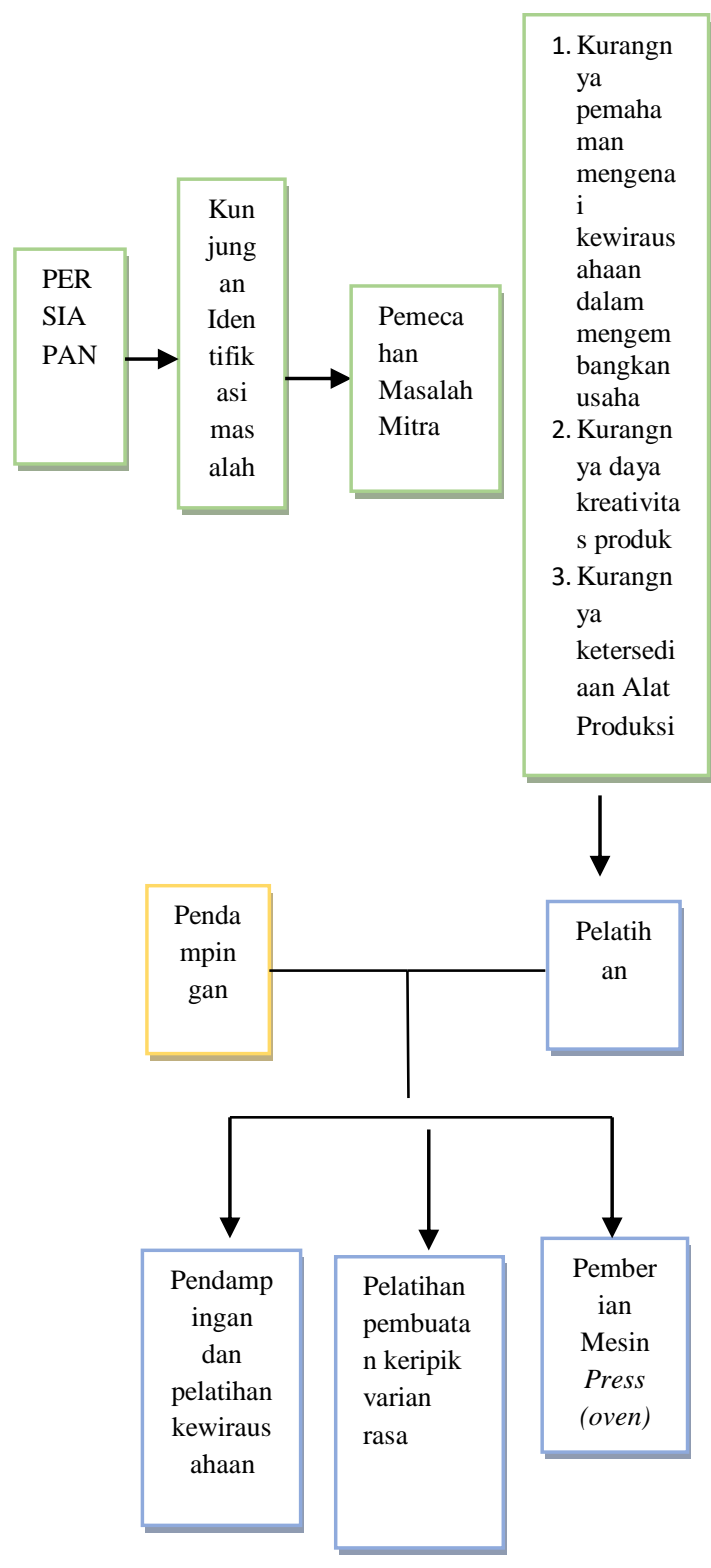

\subsection{Metode Pendekatan Yang Ditawarkan}

Melihat permasalahan yang dihadapi maka metode pendekatan yang dilakukan untuk mengatasi permasalahan mitra dan menawarkan solusi masalah bagi mitra adalah dengan memberi pemahaman mengenai kewirausahaan sebagai modal awal dalam mengembangkan usaha.

Maka model yang di terapkan oleh tim pengabdian secara skematis di gambarkan sebagai berikut: 


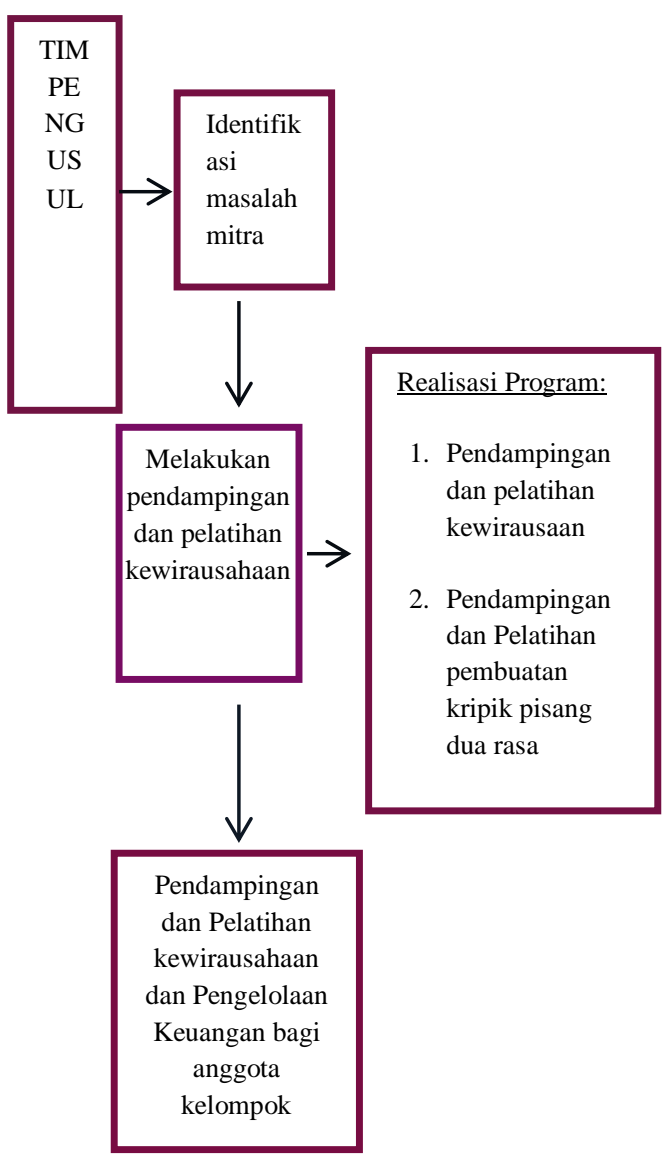

\subsection{Partisipasi Peserta dalam Pelaksanaan Program}

Partisipasi peserta dalam kegiatan ini diperlukan untuk keberhasilan pendampingan dan pelatihan yang di lakukan. Pada dasarnya anggota kelompok memahami dengan baik pentingnya berwirausaha untuk meningkatkan kesejahteraan hidup. Tetapi, disisi lain mereka juga harus selalu mengalami kendala, khususnya kendala modal, dan alat, serta kurangnya sumberdaya yang terampil. Anggota kelompok dalam kegiatan ini sangat berperan memberikan masukan apa saja yang dianggap perlu untuk meningkatkan jumlah produksi. Mereka juga memberikan pertanyaan, ide dan masukan kepada instruktur untuk meningkatkan pengetahuan mereka.

Partisipasi mitra dalam program pengabdian ini tentu diperlukan dalam mensukseskan terlaksananya program Pengabdian Masyarakat ini, antara lain: kemauan untuk meningkatkan kemampuan membuat keripik pisang dengan varian yang berbeda, niat dan tekad yang serius dalam menekuni usaha untuk meningkatkan taraf kehidupan sebagai usaha untuk mengentaskan kemiskinan. Bekerjasama dengan tim pengabdian untuk mensukseskan program kerjasama ini.

\subsection{Evaluasi Pelaksanaan Program dan Keberlanjutan Program Setelah Selesai Kegiatan Dilaksanakan}

Proses evaluasi ini dilakukan pada saat sebelum, selama dan setelah pelaksanaan kegiatan. Hasil dari pelaksanaan kegiatan ini, akan menjadi masukan untuk keberlanjutan pengabdian di tahun yang akan datang. Untuk menilai keberhasilan program kegiatan ini perlu dilakukan evaluasi atas hasil yang telah dicapai dengan terlaksananya seluruh kegiatan pengabdian. Evaluasi diberikan dengan memberikan latihan sesuai dengan pelatihan dan pendampingan yang diberikan.

Evaluasi pertama dianggap berhasil apabila peserta mampu menyampaikan bagaimana mengembangkan usaha kripik pisang dua rasa yang mereka jalankan dengan pendampingan dari tim pengabdi. Ada pernyataan kepuasan dari peserta pelatihan. Evaluasi kedua di berikan dengan memberikan latihan pencatatan transaksi usaha satu minggu sebelumnya yang terjadi pada usaha mereka. Kegiatan pendampingan ini diharapkan dapat meningkat produksi pada usaha kripik pisang ini dengan dua rasa baru. Dengan pemberian alat mesin press (oven) dapat lebih memudahkan dan melancarkan produksi kripik pisang.

Berdasarkan evaluasi yang kami lakukan dengan pengamatan dan wawancara, bahwa dengan adanya mesin tersebut sangat memudahkan pekerjaan mereka dan membantu kemajuan usaha kripik pisang dua rasa. Diharapkan kegiatan ini dapat berlanjut untuk di tahun depan dengan pelatihan yang berbeda. Jadi kami merekomendasikan agar kelompok usaha mendapatkan pelatihan keterampilan memasak yang lebih baik lagi.

\section{HASIL DAN LUARAN YANG DI CAPAI}

\section{a) Tahap Persiapan}

Tahap persiapan pada pelaksanaan kegiatan pengabdian masyarakat tahun 2017 pada UKM Melur dan Lestari yang terletak di Desa Sambirejo Timur dilakukan pada tanggal 1 Agustus 2017 yang membahas tentang persamaan persepsi, pembagian kerja, instruktur untuk pelatihan dan pendampingan, dan rangkain kegiatan yang akan dilakukan. Persiapan pelaksanaan kegiatan ini dihadiri oleh Tim Pengusul, Mitra UKM dan Tenaga lapangan.

\section{b) Pelaksanaan Kegiatan}

1) Pelatihan dan Pendampingan Kewirausahaan

Pelatihan dan pendampingan kewirausahaan di berikan kepada kedua anggota kelompok usaha yang berada di desa Sambirejo Timur. Pada awal pelatihan, di berikan pemahaman bahwa jumlah tenaga kerja ibu rumah tangga yang sangat besar ini dapat menjadi potensi besar untuk membangun perekonomian nasional. Kaum ibu yang tergolong ke dalam usia 
produktif merupakan anggota masyarakat madani dan agen perubahan yang sangat penting sehingga harus dibangun dan dipersiapkan karena akan menjadi ujung tombak dalam peningkatan daya saing Indonesia.

Dalam proses pendampingan, unsur pertama yang menjadi perhatian adalah bagaimana pendamping dapat menumbuhkan kepercayaan anggota kedua kelompok membangun kepercayaan, membentuk tim kerja kelompok, identifikasi dan mobilisasi sumber, bagaimana meningkatkan kapasitas, serta melakukan evaluasi setelah selesai pelaksanaan.

Dalam pelatihan dan pendampingan kewirausahaan ini di tekankan kepada anggota kelompok usaha bahwa jika ingin dapat berhasil dan efektif dalam menjalankan bisnisnya diperlukan dua syarat berikut, yaitu:

- Pemahaman yang benar bagaimana menjadi seorang wirausaha yang kompeten.

- Penerapan langkah-langkah teknis dan panduan yang teruji bagaimana menjalankan usaha sehingga mampu mandiri dan sukses.

Pendampingan perlu di lakukan dengan berpedoman berdasarkan analisis permasalahan yang ada serta kondisi keadaan usaha anggota yang sesungguhnya, sehingga diharapkan kegiatan ini dapat berjalan lebih berdaya guna serta tepat sasaran dan mempunyai kualitas pelaksanaan yang dapat mencapai sasaran akhir program yang diinginkan.

2) Pelatihan dan Pendampingan Pembuatan Keripik Pisang Varian Rasa

Pelatihan ini di berikan dengan cara praktek langsung yang di latih langsung oleh tim pengabdian dari Unimed, yaitu inbu Ade Chairunnisa yang mempunyai kompetensi dalam bidang tata boga. Hal yang pertama kali disampaikan adalah perlunya menjaga kebersihan dan kualitas rasa produk. Pendampingan ini di lakukan dari mulai memproses pisang menjadi keripik yang gurih tanpa di rendam dalam air kapur sirih, langsung di iris dan di goreng di wajan. Minyak yang digunakan dalam menggoreng juga bukan minyak goreng curah, karena akan mempengaruhi kualitas rasa. Minyak yang digunakan adalah minyak kemasan yang dicampur dengan sedikit mentega sehingga warnanya kuning keemasan dan rasanya juga lebih gurih.

Langkah selanjutnya tim pendamping, mempraktekkan cara pengolahan keripik pisang menjadi keripik pisang coklat dan keripik pisang keju dengan menggunakan oven. Memberikan pengetahuan kepada kedua kelompok untuk menggunakan bubuk coklat tabur dan bubuk keju tabur yang berkualitas sehingga mempengaruhi rasa. Meemberi pengetahuan kepada kedua anggota kelompok agar tidak menggunakan bahan-bahan yang membahayakan keshatan konsumen.

Langkah terakhir adalah mempacking keripik pisag keju dan coklat ke dalam wadah plastic yang bagus agar keripik tidah mudah apek dan tidah gurih lagi.

\section{3) Pemberian Oven Gas}

Oven Gas di berikan untuk menunjang produksi keripik pisang coklat dan keju. Untuk mengeringkan menggurihkan rasa keripik pisang diperlukan oven. Supaya oven dapat menghemat biaya karena tidak menggunakan minyak tanah, maka oven yang cocok untuk kegiatan produksi ini adalah menggunakan oven gas.

\section{RENCANA TAHAPAN BERIKUTNYA}

Berdasarkan kegiatan yang sudah dilakukan dengan perencanaan sebelumnya, maka rencana tahapan berikutnya, adalah:

1. Melakukan pendampingan terhadap aktivitas yang dilakukan kedua kelompok usaha untuk kegiatan produksi keripik pisang coklat dan keju atas pendidikan dan pelatihan yang telah diberikan tim pelaksana pada kegiatan pengabdian masyarakat. Terdapat beberapa aspek yang harus didampingi, yaitu aspek produksi produk dan aspek kewirausahaan.

2. Menjadikan kedua kelompok usaha sebagai kelompok usaha binaan Lembaga Pengabdian kepada Masyarakat UNIMED. Sehingga program pengabdian masyarakat ini berakhir, proses pendampingan terhadap kelompok usaha ini tetap berlanjut.

3. Ketua kelompok program pengabdian masyarakat mempublikasikan hasil pengabdian kepada masyarakat sebagai pemakalah pada kegiatan Seminar Hasil Pengabdian Masyarakat di Universitas Negeri Medan pada bulan September tahun 2017.

4. Draft publikasi untuk seminar (terlampir) telah dikirimkan ke Lembaga Pengabdian Masyarakat UNIMED.

\section{KESIMPULAN DAN SARAN}

\subsection{Kesimpulan}

Berdasarkan dari hasil kegiatan program Pengabdian masyarakat pada kelompok usaha keripik pisang di Desa Sambirejo Timur, Kecamatan Percut Sei Tuan yang sudah dilaksanakan, maka dapat ditarik kesimpulan bahwa kedua kelompok ini setelah di berikan pelatihan dan pendampingan mampu dalam membuat inovasi produk, yaitu keripik pisang coklat dan keju, yang berbeda rasa dari produk sebelumnya. Selain itu juga kedua kelomok usaha ini juga mampu mengoperasikan alat oven gas untuk membuat 
keripik pisang coklat dan keju lebih enak lagi rasanya. Setelah di berikan pendidikan dan pelatihan kewirausahaan, semangat dan keinginan serta pengetahuan anggota dalam berwirausaha akan semakin meningkat.

\subsection{Saran}

Saran yang bisa disampaikan dalam kegiatan ini adalah diharapkan adanya program kegiatan pengabdian masyarakat di Desa Sambirejo Kecamatan Percut Sei Tuan dapat juga dilaksanakan di daerah lainnya yang berpotensi untuk didampingi dan diberikan ketrampilan-ketrampilan baru atau pun program lainnya. Sehingga, akan dapat memberikan manfaat yang lebih luas dalam mendukung program pemerintah untuk mengatasi kemiskinan dan dapat meningkatkan kesejahteraan masyarakat di Indonesia.

\section{DAFTAR PUSTAKA}

DIPTI Sumatera Barat, 1998, Pemasaran Komoditas Ekspor Unggulan Propinsi Sumatera Barat.

Kelompok Kerja Pengembangan Riset dan Teknologi, Dewan Ilmu Pengetahuan, Teknologi Industri Sumatera Barat, Padang.

Satuhu dan Supriyadi, 1997, Pisang; Budidaya, Pengolahan dan Prospek Pasar, Penebar Swadaya, Jakarta.

Soekartawi, 1994, Pembangunan Pertanian, Raja Grafindo Persada, Jakarta.

Winarno, M, 1996, Strategi Pengembangan Produksi buah-buahan Untuk Pasar Domestik, Media Komunikasi dan Informasi Pangan No. 26 Volume VII 1996, Badan Urusan Logistik , Jakarta. 